\title{
Social tipping dynamics for stabilizing Earth's climate by 2050
}

\author{
Ilona M. Otto ${ }^{a, 1,2} \mathbb{D}_{\text {, Jonathan F. Donges }}^{a, b, 1,2}$, Roger Cremades $^{c} \mathbb{D}$, Avit Bhowmik ${ }^{\text {b,d }}$, Richard J. Hewitt ${ }^{e, f}$, \\ Wolfgang Lucht ${ }^{a, g, h}$, Johan Rockström ${ }^{a, b}$, Franziska Allerberger ${ }^{a, i}$, Mark McCaffrey', Sylvanus S. P. Doe ${ }^{\mathrm{k}}$, Alex Lenferna', \\ Nerea Morán $^{\mathrm{m}, \mathrm{n}}$, Detlef P. van Vuuren ${ }^{\circ, \mathrm{p}}$, and Hans Joachim Schellnhuber ${ }^{\mathrm{a}, q, 2}$
}

\begin{abstract}
${ }^{a}$ Earth System Analysis, Potsdam Institute for Climate Impact Research, Member of the Leibniz Association, 14473 Potsdam, Germany; ${ }^{b}$ Stockholm Resilience Centre, Stockholm University, 11419 Stockholm, Sweden; 'Climate Service Center Germany (GERICS), 20095 Hamburg, Germany; ${ }^{d}$ Risk and Environmental Studies, Karlstad University, SE 65188 Karlstad, Sweden; 'Information and Computational Sciences Group, James Hutton Institute, Craigiebuckler, Aberdeen AB15 8QH, Scotland, United Kingdom; ' ${ }^{\mathrm{f}}$ Observatorio para una Cultura del Territorio, 28012 Madrid, Spain; ${ }^{9}$ Department of Geography, Humboldt University, 10099 Berlin, Germany; ${ }^{h}$ Integrative Research Institute on Transformations of Human-Environment Systems, Humboldt University, 10099 Berlin, Germany; 'Department of Geography, University of Innsbruck, 6020 Innsbruck, Austria; 'UN Climate Change community for Education, Communication and Outreach Stakeholders (ECOS), 3046 Kisbágyon, Hungary; ${ }^{k}$ GeoSustainability Consulting, Adabraka-Accra, Ghana; 'Department of Philosophy, University of Washington, Seattle, WA 98195-3350; ${ }^{\mathrm{m}}$ Germinando Sociedad Cooperativa Madrid, 28012 Madrid, Spain; ${ }^{\mathrm{n}}$ Foro de Transiciones, 28011 Madrid, Spain; ${ }^{\circ}$ Climate, Air and Energy, PBL Netherlands Environmental Agency, 2594 AV Den Haag, The Netherlands; ${ }^{\mathrm{P} C o p e r n i c u s ~ I n s t i t u t e, ~ U t r e c h t ~ U n i v e r s i t y, ~} 3584$ CB Utrecht, The Netherlands; and 'Department of Earth System Science, School of Science, Tsinghua University, Haidian District, Beijing 100084, People's Republic of China
\end{abstract}

Contributed by Hans Joachim Schellnhuber, November 15, 2019 (sent for review January 22, 2019; reviewed by J. David Tabara and Jessika E. Trancik)

\begin{abstract}
Safely achieving the goals of the Paris Climate Agreement requires a worldwide transformation to carbon-neutral societies within the next $30 \mathrm{y}$. Accelerated technological progress and policy implementations are required to deliver emissions reductions at rates sufficiently fast to avoid crossing dangerous tipping points in the Earth's climate system. Here, we discuss and evaluate the potential of social tipping interventions (STIs) that can activate contagious processes of rapidly spreading technologies, behaviors, social norms, and structural reorganization within their functional domains that we refer to as social tipping elements (STEs). STEs are subdomains of the planetary socioeconomic system where the required disruptive change may take place and lead to a sufficiently fast reduction in anthropogenic greenhouse gas emissions. The results are based on online expert elicitation, a subsequent expert workshop, and a literature review. The STIs that could trigger the tipping of STE subsystems include 1) removing fossil-fuel subsidies and incentivizing decentralized energy generation (STE1, energy production and storage systems), 2) building carbon-neutral cities (STE2, human settlements), 3) divesting from assets linked to fossil fuels (STE3, financial markets), 4) revealing the moral implications of fossil fuels (STE4, norms and value systems), 5) strengthening climate education and engagement (STE5, education system), and 6) disclosing information on greenhouse gas emissions (STE6, information feedbacks). Our research reveals important areas of focus for larger-scale empirical and modeling efforts to better understand the potentials of harnessing social tipping dynamics for climate change mitigation.
\end{abstract}

climate change | Paris Agreement | decarbonization | social tipping elements | social tipping interventions

D reventing dangerous climate change and its devastating consequences is a defining task for humanity $(1,2)$. It is also an indispensable prerequisite for achieving sustainable development $(3,4)$. Limiting global warming to $1.5^{\circ} \mathrm{C}$ as stipulated in the Paris Climate Agreement (5) scientifically implies a complete net decarbonization of the world's energy and transport systems, industrial production, and land use by the middle of this century. In their "roadmap for rapid decarbonization," Rockström et al. (6) highlight that rapid increase of the share of zero-carbon energy within the global energy system would be needed to achieve this objective, likely alongside a considerable strengthening of terrestrial carbon sinks. In one scenario, the zero-carbon share of the energy system doubles every 5 to $7 \mathrm{y}$ for the next several decades (6). Carbon emissions that are currently still on the rise at rates of 0 to $2 \%$ per year, despite decades-long efforts in international climate negotiations, would thereby need to pivot to a rapid decline of ultimately $7 \%$ per year and more. These emission reduction rates would surpass by far even those experienced only during periods of massive socioeconomic crisis in the 20th century, such as World War II and the collapse of communism (Fig. 1).

Here, the historically decisive question is whether and how such rapid rates of deployment can be collectively achieved. Current deployment rates of low-carbon energy sources are compatible with the required shift but when scaled up are expected to encounter considerable resistance due to the rigidities inherent in political and economic decision making $(7,8)$, as well as new technological demands $(9,10)$. Although an increasing number of countries have already introduced or are committed to introducing carbon pricing, the initiatives covered by carbon pricing included only $15 \%$ of global greenhouse gas emissions in 2017 (11) and have so far driven only marginal emission reductions (12). It is increasingly recognized that business-as-usual technological progress and carbon

\section{Significance}

Achieving a rapid global decarbonization to stabilize the climate critically depends on activating contagious and fast-spreading processes of social and technological change within the next few years. Drawing on expert elicitation, an expert workshop, and a review of literature, which provides a comprehensive analysis on this topic, we propose concrete interventions to induce positive social tipping dynamics and a rapid global transformation to carbon-neutral societies. These social tipping interventions comprise removing fossil-fuel subsidies and incentivizing decentralized energy generation, building carbon-neutral cities, divesting from assets linked to fossil fuels, revealing the moral implications of fossil fuels, strengthening climate education and engagement, and disclosing greenhouse gas emissions information.

Author contributions: I.M.O., J.F.D., R.C., A.B., W.L., J.R., and H.J.S. designed research I.M.O., J.F.D., R.C., A.B., R.J.H., F.A., M.M., S.S.P.D., A.L., N.M., and D.P.v.V. performed research; I.M.O., J.F.D., W.L., and J.R. contributed new reagents/analytic tools; I.M.O., J.F.D., R.C., A.B., and F.A. analyzed data; and I.M.O., J.F.D., R.C., A.B., R.J.H., W.L., J.R., F.A., M.M., S.S.P.D., A.L., N.M., D.P.v.V., and H.J.S. wrote the paper.

Reviewers: J.D.T., Autonomous University of Barcelona; and J.E.T., Massachusetts Institute of Technology.

The authors declare no competing interest.

This open access article is distributed under Creative Commons Attribution License 4.0 (CC BY).

II.M.O. and J.F.D. contributed equally to this work

${ }^{2}$ To whom correspondence may be addressed. Email: ilona.otto@pik-potsdam.de, donges@pik-potsdam.de, or john@pik-potsdam.de.

This article contains supporting information online at https://www.pnas.org/lookup/suppl/ doi:10.1073/pnas.1900577117/-/DCSupplemental.

First published January 21, 2020. 


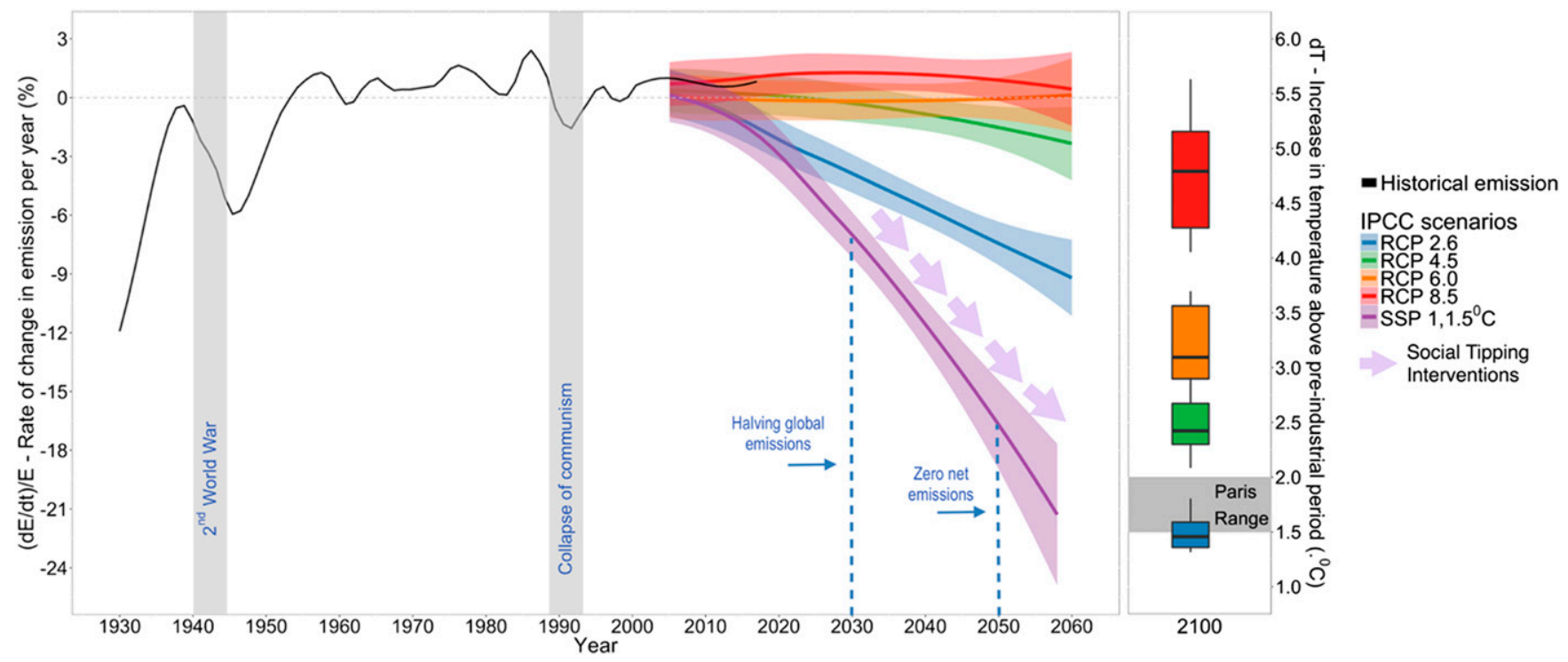

Fig. 1. The rate of change in annual greenhouse gas emissions required for net decarbonization. Social tipping dynamics in the context of the representative concentration pathways (RCPs) of the Intergovernmental Panel on Climate Change (IPCC) and the Paris Agreement. Left and Right exhibit the rate of change in $\mathrm{CO}_{2}$ emission per year between 1930 and 2060, and the increase in global mean temperature by 2100 relative to the preindustrial period, respectively, under the four RCPs. The transition to a new net decarbonized state requires shifting from an incremental rise in emissions of 0 to $2 \%$ per year to nonlinear decline at the rate of $7 \%$ per year and more (6). The figure was created using the RCP emission projections (153) and Coupled Model Intercomparison Project 5 (CMIP5) temperature projections (154).

pricing alone are not likely to lead to rapid and deep reductions in greenhouse gas emissions (13).

At the same time, there is evidence from various scientific fields demonstrating that rapid rates of change can be observed under certain critical conditions in natural (14-16), socioeconomic (17-20) and social-ecological systems (SESs) $(21,22)$. Increasing attention is being given to the concept of tipping dynamics as a nonlinear mechanism behind such disruptive system changes. Based on a review on social-ecological tipping points research, Milkoreit et al. (23) propose a common definition of social tipping points (STPs) as points "within an SES at which a small quantitative change inevitably triggers a non-linear change in the social component of the SES, driven by self-reinforcing positive-feedback mechanisms, that inevitably and often irreversibly lead to a qualitatively different state of the social system." There are historical examples of dynamic social spreading effects leading to a large self-amplification of small interventions: For example, the writings of one man, Martin Luther, injected through newly available printing technology into a public ready for such change, triggered the worldwide establishment of Protestant churches (24). An example in the field of climate policy is the introduction of tariffs, subsidies, and mandates to incentivize the growth of renewable energy production. This has led to a substantial system response in the form of mutually reinforcing market growth and exponential technology cost improvement $(25,26)$.

In this paper, we examine a number of potential "social tipping elements" (STEs) for decarbonization $(27,28)$ that represent specific subdomains of the planetary social-economic system. Tipping of these subsystems could be triggered by "social tipping interventions" (STIs) that could contribute to rapid transition of the world system into a state of net zero anthropogenic greenhouse gas emissions. The results reported in this study are based on an online expert survey, an expert workshop, and an extensive literature review (SI Appendix).

Our results complement the existing shared socioeconomic pathways (SSPs) that are used alongside the representative concentration pathways (RCPs) to analyze the feedbacks between climate change and socioeconomic factors, such as world population growth, economic development, and technological progress (29). Our results could be useful for exploring possible transformative pathways leading to scenarios that reach net zero emissions by 2050 (30).

\section{Defining STEs and STIs Relevant for Decarbonization Transformation}

Various types of tipping processes can be differentiated in the literature. Many authors refer to critical thresholds $(16,28)$, a notion closely related to the metaphor of a "butterfly effect" (31, 32). Other processes related to tipping dynamics include metamorphosis, where a rapid loss of structures of one sort occurs simultaneously with the development of new structures (33), as well as cascades driven by positive feedbacks in processes occurring simultaneously at smaller scales (34).

The social tipping dynamics of interest for this study are typically manifested as spreading processes in complex social networks $(35,36)$ of behaviors, opinions, knowledge, technologies, and social norms $(37,38)$, including spreading processes of structural change and reorganization (34). These spreading processes resemble contagious dynamics observed in epidemiology that spread through social networks (39). Once triggered, such processes can be irreversible and difficult to stop. Similar contagious dynamics have been observed in human behavior $(35,36)$, for example in assaultive violence (39), participation in social movements (40), or health-related behaviors and traits (36), such as smoking or obesity $(41,42)$.

We understand STEs as functional subsystems of the planetaryscale World-Earth system (43) consisting of interacting biophysical subsystems of the Earth, and the social, cultural, economic, and technological subsystems of the world of human societies $(43,44)$. Potential STEs share one defining characteristic: A small change or intervention in the subsystem can lead to large changes at the macroscopic level (23) and drive the World-Earth system into a new basin of attraction, making the transition difficult to reverse (20). Exact quantifications of the relationship between big and small are, however, rare, as are empirical examples (Table 1). For the combination of big interventions and big effects, there are currently no convincing examples; however, the potential use 
Table 1. Illustrative examples of intervention-and-effect relationships in the context of climate change mitigation

Intervention types

Small intervention

Big intervention
Small effect

An incremental change, e.g., a town mitigation plan (157)

Inefficient interventions, e.g., the implementation of the European Carbon Emission Trading Scheme leading to a marginal reduction of greenhouse gas emissions due to leakage effects (159)

(159)
Big effect

A tipping effect, e.g., feed-in tariffs in the German

"Energiewende" (158)

An elephant effect, e.g., reducing the Earth's carbon burden by means of solar radiation management geoengineering (160) solar radiation management geoengineering in the future would fall into this category. Finally, some changes in the World-Earth system might be driven by nonhuman and unintentional forces (e.g., a sufficiently large meteorite hitting the Earth or a disease outbreak), while others might be driven by conscious interventions of human agency (45).

Tipping processes might be analyzed as a function of change in a suitably selected forcing variable or control parameter $(15,27)$. The pertinent World-Earth system features such as the anthropogenic carbon emissions are commonly the product of complex interactions of multiple drivers. These factor can, however, in some cases be combined into a single dominant control parameter.

In this study, we identify a subsystem of the World-Earth system as a STE relevant for decarbonization transformation if it fulfils the following criteria:

C1. A set of parameters or drivers controlling its state can be described by a combined control parameter that after crossing a critical threshold (the STP) by a small amount influences a crucial system feature of relevance (here the rate of anthropogenic greenhouse gas emissions) leading to a qualitative change in the system after a reference time has passed allowing for the emergence of the effect (15).

$\mathrm{C} 2$. It is possible to differentiate particular human interventions leading to the small change in the control parameter that has a big effect on the crucial system feature, which will be referred to as the STI (Fig. 2).

Established social systems, including their infrastructures, while they may partly be open to change, tend also to possess selfstabilizing mechanisms that oppose change, be it through infrastructural inertia due to investment cycles or cultural or political inertia due to deeply held traditions or power structures all representing aspects of social complexities (Fig. 2 and refs. 46 and 47). For this reason, a cumulation of effects due to social contagion, repetitive nudging, or direct intervention can lead to social tipping dynamics (48). Starting points for such cumulations of effects are here called STIs. Naturally, their existence, nature, and point of departure are a function of the cumulated history of the respective social system and, in that sense, STIs and social tipping dynamics are path dependent.

Following Rockström et al. (6), in order to achieve the Paris Climate Agreement's goals and to avoid higher levels of global warming at the end of this century that would imply crossing dangerous tipping points in the Earth's climate system (27), global anthropogenic carbon emissions would need to be halved every decade, achieving a peak in 2020 and then steadily decreasing to reach net zero emissions by 2050 . Achieving net zero global emissions around 2050 is necessary for there to be a significant probability of limiting global warming to $1.5^{\circ} \mathrm{C}$ by the end of the century (1). To ensure that the social tipping dynamics identified in this study are compatible with these constraints, we impose the following filtering criteria:
F1. The time needed to trigger the tipping should not exceed $\sim 15 \mathrm{y}$, and the time needed to observe a qualitative change at the whole system level should not exceed $\sim 30 \mathrm{y}$ (Fig. 1).

F2. Since abrupt social changes have historically often been associated with social unrest, war, or even collapse (49), human intervention and its foreseeable effects should here be explicitly compatible with the Sustainable Development Goals (50), in the sense of positive social tipping dynamics (34).

Finally, due to the networked and multilevel character of the social system (51), we also ask about the feedback mechanisms connecting and potentially mutually reinforcing the identified candidates for STEs and STIs.

\section{Results}

Candidates for STEs from Expert Elicitation. Both natural and social systems are characterized by a high level of complexity and are linked by coevolutionary dynamics (52). Isolating the elements of such systems is difficult. Although we provided our respondents with a written definition of a STE, most of the online survey participants referred to what we define as STIs. On the basis of the responses, 12 groups of candidates for STEs could be identified, each referring to a distinctive control parameter (Table 2). The critical threshold of the control parameter needed to be crossed in order to trigger the tipping process was in most of groups not quantified by the experts but described qualitatively. The STP was often referred to as the point when a certain belief, behavior, or technology, spreads from a minor tendency to a major practice. Documented instances of technology and business solutions show that a 17 to $20 \%$ market or population share can be sufficient to cross the tipping point and scale up to become the dominant pattern (53). Some authors, however, argue that it must be the "right" share of population, including well-connected influential people, trendsetters, and other types of social leaders with a high degree of agency $(38,54)$. In other cases, the experts referred to the STP that would be achieved if the price of fossil-fuel-free products and services falls below that of those products and services based on fossil fuels. Table 2 presents an overview of expert elicitation results.

Critical Interventions for Inducing Social Tipping Dynamics. Building upon the results of our expert elicitation, we differentiated six key candidates for STEs and associated STIs for which we were able to find empirical material showing that they fulfill the conditions specified in our definition (as listed in Table 3 ). These do not necessarily comprise a comprehensive list of "silver bullet" solutions; rather, this is an initial selection that can help in developing more refined socioeconomic rapid transformation pathways and narratives customized at appropriate scales. Below, we present a review of literature on each of the STEs and STIs nominated by the experts. We search for evidence supporting the potential of the interventions to trigger tipping-like changes in their domains leading to a qualitative change at the World-Earth system level; we ask whether critical thresholds in 


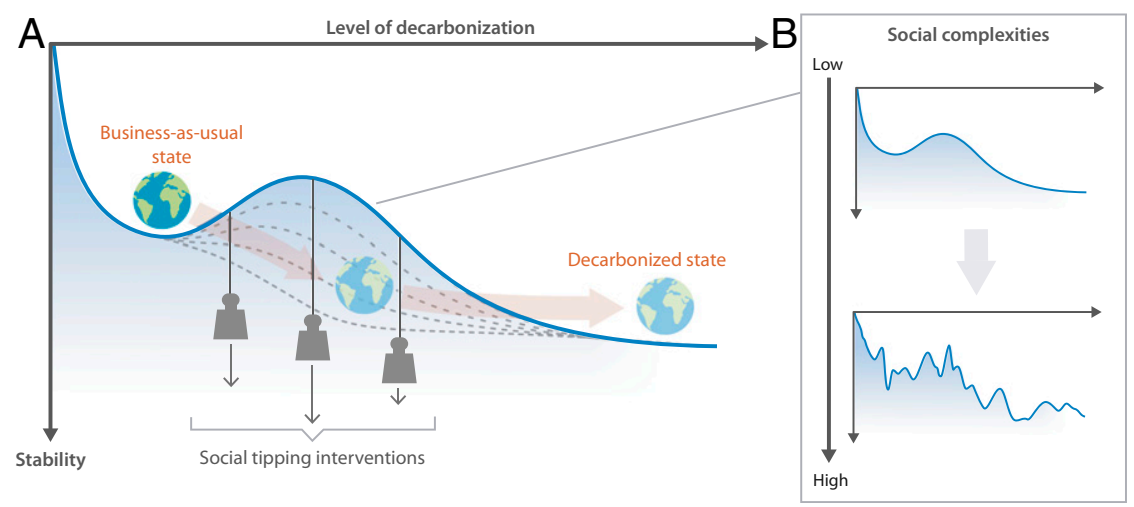

Fig. 2. The concept of decarbonization transformation as social tipping dynamics. As illustrated in $A$ by an abstract stability landscape (155), the world's socioeconomic system today is trapped in a valley where it still depends heavily on burning fossil fuels, leading to high rates of greenhouse gas (GHG) emissions. STIs have the potential to erode the barrier through triggering social tipping dynamics in different sectors (Fig. 3 ) and thus paving the way for rapid transformative change. Uncertainties and complexities inherent in the many dimensions of human societies beyond their level of decarbonization (46) can be envisioned as forming a rougher stability landscape featuring multiple attracting states and a larger number of barriers that need to be eroded or overcome $(B)$. This inherent "social noise" may complicate transformative change but could also accelerate it by means of dynamical phenomena such as stochastic resonance (156).

the control parameters can be determined; and finally we begin to examine the interactions and feedbacks among the identified tipping elements.

STIs in the energy production system. The technological development in the energy production system is a dominant element of the decarbonization discussions in international institutions $(55,56)$ and business partnerships (57). The results of our expert elicitation confirm that technology development is likely to play a key role, however, not in the sense of yet-to-be invented technological solutions, but rather in the adaptation of existing carbon-free technology primarily in the power sector and by facilitating a smarter utilization of energy. The main control parameter that drives the adaptation of fossil-fuel-free energy technology is associated with the financial returns of its adoption (58). Our expert group believed that the critical condition needed to trigger the tipping process is the moment when fossil-fuel-free energy production yields higher financial returns than the energy production based on fossil fuels. The empirical data show that this critical threshold is about to be reached; the prices of renewables have dropped sharply in the last few years, and they have already become the cheapest source of energy in many world regions. The average cost of onshore wind dropped by $18 \%$, and offshore wind fell by $28 \%$ (59). The costs of photovoltaic modules fell by about $20 \%$ with every doubling of cumulative capacity since the 1970s (60) and the key role in reducing the cost of photovoltaics was played by policies that stimulate market growth (26). Optimization modeling shows that renewable energy supplies can potentially supply $100 \%$ of human power demand (61), and in theory, rapid transformation to low energy demand is possible (30) and will be cost-effective in the long run (62). However, there are large costs associated with adapting existing infrastructure and supply and demand support services to meet the demands of nondispatchable, volatile renewable sources like wind and solar in electricity generation. The question is whether the cost of transforming the energy infrastructure is worthwhile compared to the cost of inaction. The prioritization of societal preferences in the competition for scarce budgetary resources is influenced by the dominant social values (63).

Our expert group believed that redirecting national subsidy programs to renewables and low-carbon energy sources or removing the subsidies for fossil-fuel technologies are the tipping interventions that are needed for the take-off and diffusion of fossilfuel-free energy systems. The key actors who have the agency to implement these interventions include national governments and energy ministries, and the response of large energy companies is important. One-third of global industrial greenhouse gas emissions can be linked just to 29 oil and gas companies (64). The International Energy Agency has tracked fossil-fuel subsidies over the last decade and in 2009 estimated that \$312bn was spent worldwide in fossil-fuel subsidies, compared to $\$ 57 \mathrm{bn}$ on renewables in that year (65). By 2015, the gap had narrowed, but the subsidies received by fossil fuels were still more than twice those of renewables (66). Estimates show that a universal phaseout of fossil-fuel subsidies could lower annual carbon emissions by $4.4 \%$ (67). Coady et al. (68) argue that eliminating subsidies for fossil fuels would have reduced global carbon emissions in 2013 by $21 \%$.

Furthermore, our expert group believed that the global energy production and storage system can also be radically changed by decentralization of energy production. Since large power stations relying on coal, oil, or gas exploitation are not profitable below a certain threshold of households supplied, decentralized generation systems and transitioning to local power generation might be expected to lead to a virtually complete decarbonization of production systems $(69,70)$. However, this is also likely to lead to an increase in costs due to the loss of economies of scale (69), and the complexities of integrating variable, distributed power sources (71). This emphasizes the need for decentralized energy generation and demand management to be part of the wider energy systems transformation (72). It has been argued that citizens also have a major role to play as nodes in a smart system capable of facilitating flexible demand management (73). Some authors also warn that meeting current levels of demand (let alone future projected demand) with renewables alone is likely to be extremely difficult $(74,75)$. Nonetheless, interest in decentralized control of energy systems is growing. Across the Global North, there are a multitude of examples of energy cooperatives and communitydriven energy projects (76). Such projects have often found creative ways to overcome limitations imposed by centralized distribution networks, e.g., by using smart technologies to divert excess power for local heating (77), or by bringing municipal supply networks into community ownership (78). They show such initiatives may also spark around the Global South by skipping the "megadevelopment" phase associated with large power stations and massive grid infrastructure expansion. Due to the positive knowledge and technology spillover effects from such decentralized systems, the technology costs are likely to be further reduced with their increased diffusion $(79,80)$. The time elapsing between the planning phase and actual installation and utilization of decentralized energy generation is reportedly less than $10 \mathrm{y} \mathrm{(81).}$ 
Table 2. The candidates for social tipping elements for rapid decarbonization identified by expert elicitation

Candidates for social Key actors able to influence

tipping elements

Climate policy

enforcement

$n^{*}=42(20 \%)$;

Conf. $^{\dagger}=3$

$n=37(17 \%)$; Conf.=3

Scientific community,

media, citizen

organizations, industry

Financial market

International agencies,

$n=26(12 \%)$; Conf.=3.6 national and local

governments, financial

sector, industry

Energy production and
storage

$n=24(11 \%)$; Conf.=3.8

Conventional and green industries, national and local governments, NGOs, public-private partnerships

$\begin{array}{cc}\text { Knowledge system } & \text { Intellectual leaders, } \\ \begin{array}{cc}n^{*}=16(7,7 \%) ; & \text { scientific community, } \\ \text { Conf. }{ }^{+}=3.7 & \text { media }\end{array}\end{array}$

Other technology

$n=15(7 \%)$; Conf. $=4$

Industry, governments, media, agro-industry

Values and norms $n=12(6 \%)$; Conf. $=3$

Spiritual leaders, media, young generation, middle class

Human settlements $n=10(5 \%)$; Conf. $=3.7$

Industry, city authorities, governments

Food and car industry,

Lifestyles

$n=10(5 \%)$; Conf. $=3.7$

writers, wealthy

fashionable people, media

Citizenship involvement Civic and nonprofit

$n=7$ (3.8\%); Conf.=3.1 organizations, media, the public

Education system Scientists, teachers,

$n=5(2.4 \%)$; Conf. $=3.2$ educational ministries

\footnotetext{
Population control

Political leaders, religious

$n=3(1.4 \%)$; Conf. $=2.3$
}

The share of products and services containing GHG emission information

Market value of fossilfuel extraction and industry

The relative price of fossil-fuel-free energy production and storage

The number of people having worldviews accounting for socioecological complexities

Energy demand

The perception of fossil fuels as immoral

The demand for fossilfuel-free technology

Number of people choosing fossil-fuel free products

Citizenship commitment to climate mitigation

The presence of climate change and relevant concepts in the public education

The number of greenhouse gas emitters
Critical threshold in the control parameter

Eliminating the use of fossil fuels from most of sectors and spheres of human life circular economy; limiting the use of fossil fuels sector by sector; banning advertisement of fossil-fuel products: abolishing the trade in fossil fuels

Adequate information on emissions of products and services; labeling; growing awareness of global risks and health consequences

Carbon taxes and permits; Divesting; reinvesting; national banks warning commercial banks to reduce risk with carbon-intensive investments

Cessation of subsidies for fossilfuel technologies; decentralized and distributed energy generation; renewable energy deployment; community energy hubs; nuclear energy deployment

Reconceptualization of economics and valuation measures; convincing narratives of what can be gained from decarbonization; indigenous approaches to nature

Digitalization of the economy; tele-working; e-mobility; artificial meat; multipurpose farm-ponds

A new set of moral and ethical codes; revealing the moral implications of fossil fuels, stigmatization of fossil fuels Reallocation and redesigning of human settlements; energy independent housing; new building materials; carbonneutral cities

Vegetarian diets; lower consumption; fossil-fuel free consumption

The GHG emissions information visible for most of products and services

The market value decreasing rapidly in comparison with other comparable investments

The price of fossil-fuel-free energy becoming lower than the price of fossilfuel energy

The worldviews spreading from the minority to the majority of key actors

Energy demand reduced to a level that can be sustainably produced

Spreading from the minority to the majority of key actors

Fossil-fuel-free technology becoming the first choice in new infrastructure projects

Spreading from the minority to the majority of the population

Grassroots organizing resistance; a From a minor tendency to a global network of social movements global citizen movement

New educational programs at all levels of public education including climate change, ecological networks, system thinking

Limiting human population growth
The relevant concepts becoming a part of the main curriculum

Population decreasing to a number that can be sustainably supported

${ }^{*} n$ : The frequency of survey answers is referring to the number of the survey answers refereeing to this topical area and a share (percentage) of total survey answers.

${ }^{\dagger}$ Conf.: How confident are you that the associated social tipping point is actually going to take place and contribute substantially to a rapid and complete global decarbonization by 2050 ? 1, Very uncertain; 2 , uncertain; 3, rather uncertain, 4, rather confident; 5 , confident; 6 , very confident. 
Table 3. Synthesis of the research results on the key candidates for social tipping elements selected by the experts and their associated social tipping interventions

\begin{tabular}{|c|c|c|c|c|c|c|}
\hline $\begin{array}{l}\text { Social tipping } \\
\text { element }\end{array}$ & $\begin{array}{l}\text { Social tipping } \\
\text { intervention }\end{array}$ & $\begin{array}{c}\text { Control } \\
\text { parameter }\end{array}$ & Key actors & $\begin{array}{l}\text { GHG emission } \\
\text { reduction potential }\end{array}$ & $\begin{array}{l}\text { Dominant social } \\
\text { structure level }\end{array}$ & $\begin{array}{l}\text { Estimated time } \\
\text { needed to } \\
\text { trigger tipping }\end{array}$ \\
\hline \multirow[t]{2}{*}{$\begin{array}{l}\text { STE1: Energy } \\
\text { production } \\
\text { and storage }\end{array}$} & $\begin{array}{l}\text { STI1.1: Subsidy } \\
\text { programs }\end{array}$ & $\begin{array}{c}\text { The relative price } \\
\text { of fossil-fuel- } \\
\text { free energy }\end{array}$ & $\begin{array}{l}\text { Governments, } \\
\text { energy ministries, } \\
\text { big energy } \\
\text { producers (68) }\end{array}$ & $\begin{array}{l}\text { Up to } 21 \% \text { globally } \\
\text { in } 1 \text { y (68) }\end{array}$ & National policy (68) & $\begin{array}{l}10 \text { to } 20 y \\
\text { (including the } \\
\text { policy- } \\
\text { formative } \\
\text { phase) (161) }\end{array}$ \\
\hline & $\begin{array}{l}\text { STI1.2: Decentralized } \\
\text { energy } \\
\text { production }\end{array}$ & & $\begin{array}{l}\text { Citizens, } \\
\text { communities (73), } \\
\text { local governments } \\
\text { (162), policy } \\
\text { makers (163), } \\
\text { energy planners } \\
\text { (164) }\end{array}$ & $\begin{array}{l}\text { Up to } 100 \% \text { in power } \\
\text { supply }(61)\end{array}$ & $\begin{array}{l}\text { Community/town } \\
\text { governance (165) }\end{array}$ & $\begin{array}{l}\text { Less than } 10 \mathrm{y} \\
\quad(81)\end{array}$ \\
\hline $\begin{array}{l}\text { STE2: Human } \\
\text { settlements }\end{array}$ & $\begin{array}{l}\text { STI2.2: Carbon- } \\
\text { neutral cities }\end{array}$ & $\begin{array}{l}\text { The demand for } \\
\text { fossil-fuel-free } \\
\text { technology }\end{array}$ & $\begin{array}{l}\text { City administration, } \\
\text { citizens, and } \\
\text { citizen groups } \\
\text { (166) }\end{array}$ & $\begin{array}{l}\text { Reduction by } 32 \% \text { in } \\
14 \text { y (91) }\end{array}$ & $\begin{array}{l}\text { Urban governance } \\
\text { (91) }\end{array}$ & $\begin{array}{c}\text { Approximately } \\
10 \text { y (91). }\end{array}$ \\
\hline $\begin{array}{l}\text { STE3: Financial } \\
\text { market }\end{array}$ & $\begin{array}{l}\text { STI3.1: Divestment } \\
\text { movement }\end{array}$ & $\begin{array}{l}\text { Profitability of } \\
\text { fossil fuel } \\
\text { exploitation }\end{array}$ & $\begin{array}{l}\text { Financial investors } \\
\text { (96) }\end{array}$ & $\begin{array}{l}26 \% \text { emissions tied to } \\
\text { investments of a large } \\
\text { Canadian university } \\
(167)\end{array}$ & $\begin{array}{c}\text { Market exchange, } \\
\text { enterprise (98) }\end{array}$ & $\begin{array}{l}\text { Very rapid, could } \\
\text { occur } \\
\text { within hours } \\
(142)\end{array}$ \\
\hline $\begin{array}{l}\text { STE4: Norms and } \\
\text { values system }\end{array}$ & $\begin{array}{l}\text { STI4.1: Recognition } \\
\text { of the immoral } \\
\text { character of fossil } \\
\text { fuels }\end{array}$ & $\begin{array}{l}\text { The perception } \\
\text { of fossil fuels } \\
\text { as immoral }\end{array}$ & $\begin{array}{l}\text { Peer groups, } \\
\text { environmental } \\
\text { organizations, } \\
\text { youth, opinion } \\
\text { leaders (168-170) }\end{array}$ & Unprecedented & $\begin{array}{l}\text { Informal } \\
\text { institutions, } \\
\text { enforcement } \\
\text { through peer } \\
\text { groups (171) }\end{array}$ & 30 to 40 y (172) \\
\hline $\begin{array}{l}\text { STE5: Education } \\
\text { system }\end{array}$ & $\begin{array}{l}\text { STI5.1: Climate } \\
\text { education and } \\
\text { engagement }\end{array}$ & $\begin{array}{l}\text { Climate change } \\
\text { and impacts } \\
\text { awareness }\end{array}$ & $\begin{array}{l}\text { Teachers, climate } \\
\text { educators (117), } \\
\text { youth (113) }\end{array}$ & $\begin{array}{l}\text { Up to } 30 \% \text { reduction in } \\
2 y \text { in the emissions of } \\
\text { the Italian } \\
\text { households included } \\
\text { in the study (124) }\end{array}$ & National policy (173) & 10 to 20 y (173) \\
\hline $\begin{array}{l}\text { STE6: } \\
\text { Information } \\
\text { feedback }\end{array}$ & $\begin{array}{l}\text { STI6.1: Emission } \\
\text { information } \\
\text { disclosure }\end{array}$ & $\begin{array}{l}\text { The number of } \\
\text { products and } \\
\text { services } \\
\text { disclosing their } \\
\text { carbon } \\
\text { emissions }\end{array}$ & $\begin{array}{l}\text { The business and } \\
\text { producers; } \\
\text { governments for } \\
\text { setting disclosure } \\
\text { guidelines and } \\
\text { regulations (174) }\end{array}$ & $\begin{array}{l}\text { Up to } 10 \% \text { reduction of } \\
\text { emissions in UK } \\
\text { households' grocery } \\
\text { consumption in a year } \\
(175)\end{array}$ & $\begin{array}{l}\text { Market, exchange } \\
\text { (176); enterprise } \\
(177)\end{array}$ & A few years (178) \\
\hline
\end{tabular}

However, existing energy systems and infrastructure are likely to shape the future for decades to come (82).

STIs in human settlements. Direct and indirect emissions from buildings account for almost $20 \%$ of all carbon emissions, and we observe an unprecedented scale of global urbanization; each week the global urban population increases by 1.3 million (55). The average life span of buildings is about $50 \mathrm{y}(83)$. Public infrastructure and planning structures can last even longer (50 to $150 \mathrm{y}$ ) and play an active role in both climate mitigation and adaptation (84). Modifying building codes for construction and infrastructural projects can actively drive the demand for fossilfuel-free technologies and are crucial especially for countries in the Global South, where building booms are driving up energy and other resource use (85). An example of a STI in this realm is the creation of large-scale demonstration projects such as carbonneutral cities. These are important in order to educate the general public and stimulate consumer interest in environmental technologies, accelerating their dissemination and commercialization (85). In addition, local technology clusters create positive spillover effects of lowering the information and transaction costs (86), which can indirectly lead to a reduction in the costs of fossil-fuelfree technologies for energy production and storage. The critical conditions for social tipping in this control parameter would be achieved if the fossil-fuel-free technology became the first choice for new construction and infrastructure projects. There are many new construction materials that not only imply lower emissions but also could actively support carbon sequestration efforts in urban areas. To give an example, constructing a 142-m-high residential building using above $80 \%$ laminated timber could lead to sequestrating 21,040 tons $\mathrm{CO}_{2}$ and avoiding 50,000 tons $\mathrm{CO}_{2}$ emissions otherwise entailed in using standard construction materials such as steel and concrete, which is equivalent to the amount 33,000 cars emit per year (87). In addition, large-scale public infrastructure investments support the emergence of a shared belief in the emerging new social equilibrium that can help individuals coordinate changes and find new focal points (88). The example of the Transition Town Movement that started in 2006 in the United Kingdom and in 2014 spanned over 41 countries shows how local grassroots initiatives can encourage citizens to take direct action toward lowering energy demand and building local resilience despite lack of policy support at national levels (89). Another example includes the Energy Cities Association, whose primary goal is to accelerate the transition to sustainable energy in urban areas in Europe. The Association was created in 1990 and currently represents more than 1,000 towns and cities in 30 countries (90). The evidence from a case study on communities implementing plans for zero 
emissions shows that these communities were able to reduce their per-capita emissions by $32 \%$ in 14 y (91).

STIs in the financial system. The financial crisis in 2008 demonstrated how rapidly changes in the market value of assets in one sector and country can propagate and destabilize the global system of human societies and accelerate changes at the level of individual investment and consumption behavior as well as collectiveorganizational and policy responses (92). Maintaining global warming below $2{ }^{\circ} \mathrm{C}$ implies that $33 \%$ of oil, $49 \%$ of gas, and $82 \%$ of coal resources should not be burned (93). This suggests there might be a risk of a carbon bubble, caused by the financial exposure from stranded assets, which could be driven by policy, technological innovation, or investors' decisions (94). A growing number of analysts believe a financial bubble is emerging that could burst when investors' belief in carbon risk reaches a certain threshold (95). Simulations show that just $9 \%$ of investors could tip the system, inducing other investors to follow (96). An example of an intervention that can lead to a rapid decline in the control parameter-the value of fossil-fuel assets-is the divestment movement; as it progresses, it results in the reduction of the value of fossil-fuel assets (97). The movement started with a student campaign in 2011 and is quickly expanding to other countries and types of asset owners. The value of investment funds committed to selling off fossil-fuel assets reached \$5.2tn in 2016, doubling in just over a year and permeating enterprises in every sector of society, with examples including universities, faith groups, pension funds, and insurance companies (98). Ritchie and Dowlatabadi (94) present model scenarios showing that a major Canadian university could reduce the greenhouse gas emissions tied to its investments by up to $26 \%$ by restructuring its portfolios, moving investments away from greenhouse gas-intensive sectors. Many divestment campaigns have an additional "divest to reinvest" element that advocates using funds invested in fossilfuel companies to reinvest in socially and environmentally beneficial projects, such as low-carbon and renewable schemes (99), creating the positive-feedback interactions with the STE1. An avalanche effect would be triggered if national banks and insurance companies warned against the global risk associated to stranded assets from fossil-fuel projects. These concerns are growing in Europe, and there are already signs of a tipping point, namely cuts in financial and insurance support for coal projects (100). Norwegian financial authorities might soon be divesting the country's sovereign wealth fund. Around $6 \%(€ 30 \mathrm{bn})$ of this fund's wealth is invested in oil and gas companies (101).

STIs in the system of norms and values. The extraction and use of fossil fuels out of line with the Paris Climate Agreement targets is arguably immoral, as it would cause widespread grave and unnecessary harm (97). The impact of greenhouse gas emissions disproportionately affects the most vulnerable social groups, such as women and children (102). It also affects the well-being of future human generations (103) and causes many direct negative health effects (104). Historical cases show that social and moral norms can affect human behavior on a large scale (38). The abolition of the transatlantic slave trade, for example, showed that changes in the ethical perception of slave labor at that time were consciously initiated by a small group of intellectuals (105). Revealing the moral implication of the continued burning of fossil fuels is an example of an intervention that is likely to induce a tipping process through changes in the human normative system, i.e., the system of moral and behavioral norms that influence what is rewarded and desired in the society. Norms can develop through social networks in neighborhoods or workplaces and support certain lifestyles or technology choices (106). A study on the installation of photovoltaic panels by home owners showed social networks and dwelling proximity explained the owners' decision to install photovoltaic panels on their homes (107). The control parameter is represented by the ethical perception of fossil fuels, the environmental externalities they generate, and the broader harm they visit on societies. The critical condition in the control parameter will be achieved if the majority of social and public opinion leaders recognize the ethical implications of fossil fuels and generate pressure in their peer groups to ostracize the use of products involving fossil fuel burning. This could be more widespread in religious communities and be led by spiritual leaders, perhaps following the example of Pope Francis's encyclical Laudato si' (108). It could alternatively be manifested as a secular trend originating mainly from young, intellectually and social justice-oriented groups of people who might actively stand against supporters of fossil fuels - these would include extraction and utilization companies, governments supporting the latter, as well as the superrich family clans generating wealth from fossil fuel extraction and utilization in the last $150 \mathrm{y}$. The wealth of about $11 \%$ of the world's billionaires is related to energy production (excluding solar and wind), mining, and other natural resource utilization (109). Recent experimental evidence shows that dominant social conventions or established behavior can be changed by committed minorities of roughly $25 \%$ of a group (36). Social norms are the sources of law (110); therefore, recognizing the immoral character of fossil fuels can further lead to regulations restricting the use and extraction of fossil fuels (111).

The time elapsing from the recognition of the activity as a problem and as a matter of a moral choice by international legal scholars, religious groups, and other moral entrepreneurs, to international delegitimization might range from a few decades to a few centuries. The slavery abolition movement started in 1772 in England and led to the abolition of the slave trade in 1807 and in the 1833 to the total abolition of slavery in the British Empire. The historical data show that although the number of slaves traded in the British Empire dropped to zero by 1826, the number of internationally traded slaves started to decrease around the mid-19th century. However, after reaching its peak, the number of slaves traded internationally decreased exponentially within just a few years. In the period 1851 to $1860,71 \%$ fewer slaves disembarked than in the period 1841 to 1850 (https://slavevoyages.org/). A more recent example of outlawing the use of substances responsible for ozone depletion showed that such changes might occur in less than $30 \mathrm{y}$ (112). However, the financial and political power of the fossil fuel industry suggests the need for much more substantial political effort to ensure such a change, than would have been the case for the issue of ozone depletion (99). There is recent anecdotal evidence that protests, such as the \#FridaysForFuture climate strikes of school students around the world, the Extinction Rebellion protests in the United Kingdom, and initiatives such as the Green New Deal in the United States, might be indicators of this change in norms and values taking place right now (113).

STIs in the education system. Many examples of research confirm the role of education in social transformations (114) and tackling climate change concerns $(115,116)$. The control parameter that relates to this intervention is the coverage of climate change issues in school and university teaching programs. While many teachers include some, often thin, coverage of climate change (117), comprehensive approaches at all levels of public education are still rare. Lack of knowledge about the causes, impacts, and solutions to climate change was the most easily identifiable individual barrier to engagement in climate action in the United Kingdom (118). At the same time, studies show that the divergent ways of understanding climate change draw on discourses broader than scientific knowledge; these differences may be blamed for misinterpretation of scientific notions such as uncertainty (119) as well as for the tendency to attribute responsibility for causing and mitigating climate change to others (118). Formal and lifelong education is traditionally considered a slow and evolving process, but there are examples of rapid change that can be generated. Quality education supports and amplifies norms and values and can quickly inspire behavior change among individuals and their cohorts. In addition, massive literacy campaigns, such as the one 
that took place in Cuba in the 1950s, where in a less than a year illiteracy was reduced from 24 to $3.9 \%$ (120), demonstrate the potential for rapid societal transformation. The effects of changes in educational programs can also lead to a social tipping process as soon as the new generation enters the job market and public decision-making bodies. The recent \#FridaysForFuture protests demonstrate the upcoming new generation might radically change the political scene. It is estimated that within just half a year the school children movement grew to 1.5 million students in 125 countries. The effects of educational campaigns can be strengthened by a supportive family and community context as well as by media campaigns, advertising bans, higher taxes, use prohibitions, and lawsuits against producers (121). Warner (122) shows that combined educational and mass-media campaigns in the 1970 s in the United States led to 4 to 5\% annual decrease in cigarette consumption. In the climate change context, Dietz et al. (123) show that interventions that combine mass-media messages, household- and behavior-specific information, and communication through individuals' social networks and communities could lead to reductions of $20 \%$ in household direct emissions in less than $10 \mathrm{y}$, with little or no reduction in household well-being. An educational campaign carried out in five Italian cities for $2 \mathrm{y}$, involving teachers, pupils, and citizens, resulted in an emission reduction in a range of 7 to $30 \%$ in the 247 families included in the research (124). That said, education to bolster understanding of the causes and effects of climate change, however important, will not be sufficient to transform society alone. Sustainability cannot be imposed, it has to be learned, so that is endogenously realized and enacted deliberately by the actors who constitute the SES (46). Engagement and the fostering of sustainable lifestyles and career pathways by transforming schools into living laboratories (125) is necessary to counter the often overlooked shadow side of education, since the secondary and higher levels of education are currently associated with higher resource use (126). STIs through information feedbacks. The last tipping intervention is related to the flow of information and creating positive information feedbacks. The control parameter is represented by the transparency of the impact of individual consumer and lifestyle choices and carbon emissions. Transparency and disclosure of information about carbon emissions are needed, for instance, not just to provide a solid basis for global, regional, and national policies (127) but also to increase public and consumer awareness and improve labeling programs (128), triggering action and lifestyle changes to support decarbonization (129). The recent disclosure of the close ties between RWE, the biggest energy company in Germany, and regional politicians protecting their interest in the lignite coal extraction areas in Hessen led to a nationwide social movement and massive public demonstrations against plans to clear the Hambach Forest (130). Corporate disclosure of carbon assets can also help to overcome the shortterm horizons of fund managers (131) and create a positive feedback in the divestment movement.

Another positive feedback can be identified between the information system and public education. Enhanced public knowledge and understanding by the broader public of the main variables and processes in the Earth's climate system and their linkages with human activities could increase public sensitivity to emissionsrelated information (132). Just as most product packages display nutritional facts, some authors propose they could display a second label on "Earth facts" and disclose the information on their carbon footprint and other emissions (133). In comparison, the global market for organic products, driven primarily by health concerns but clearly stimulated by providing clear labeling, increased at rates above $10 \%$ per year (134).

\section{Discussion and Conclusions}

Each of the STEs discussed above exists in the real world in varying degrees, locations, and scales and shows the potential to boost a decarbonization breakthrough. Since social-ecological dynamics are subject to complex processes that cannot be fully anticipated, it is not possible to predict when and where exactly tipping points will be crossed. However, the system can be imperfectly navigated intentionally to achieve certain desirable conditions and capacities (34). The social tipping dynamics are likely to spread through adaptive networks of interactions rather than via straightforward cause-effect systems. The identified interactions between the various STEs mean that they can potentially reinforce one another, making a transition to decarbonization more likely if several are triggered simultaneously (Fig. 3). In addition, crossing multiple tipping points in diverse systems of action increases the likelihood of breaking existing systemic inertia and lock-ins and thereby achieving the climate policy goals $(34,45)$. The interactions between the nominated candidates for STEs could be organized as different possible transformative pathways leading to crossing tipping points across scales and regions. These "tipping transformative pathways" can potentially show the bottom-up emergence of the global sustainability pathway (SSP1) (135).

One possible transformative pathway that has recently started to materialize has been initiated within the education system by school children who started the climate strikes \#FridaysForFuture. The movement is causing "irritations" in personal worldviews (136) and thus might be changing peoples' norms and values and the ways of thinking and acting, possibly leading to changes in policies and regulations, infrastructure development, as well as individual consumption and lifestyle decisions. For example, as a result of the massive school student protest in Germany, even the traditionally climate-conservative parties recently started to address climate change issues in their programs (137). The increasing awareness of the seriousness of climate change might drive an increasing demand for greenhouse-gas emission disclosure of various products and services. It might also drive an increased recognition of the intergenerationally unethical and immoral character of fossil fuels that will furthermore strengthen the legitimacy of carbon mitigation policies, including the removal of fossil-fuel subsidies. Although changes of norms, customs, and beliefs occur very slowly (138), one should keep mind that now is not year zero of the global sustainability transformation. It has now been $30 \mathrm{y}$ since the Intergovernmental Panel on Climate Change (IPCC) was endorsed by the United Nations and issued its first report recognizing the anthropogenic character of climate change, and many important milestones have been reached since then, including publishing the subsequent IPCC reports, Pope Francis's encyclical Laudato si', and numerous events led by artists and activists increasing the concern about climate issues. The example of "flight shaming" that was initiated by a Swedish Olympic athlete and has been popularized in social media (139), shows that society may now be just at the edge of tipping in the realm of social norms and beliefs. The high number of seats that environmentally oriented parities recently won in the European Union (EU) elections (140) shows that EU policy might potentially undergo a substantial shift within the next few years, the EU becoming a global leader in carbon mitigation efforts.

A global breakthrough could also be initiated at the level of resource allocation by redirecting financial flows in line with the divestment movement and improving information feedbacks by disclosing the greenhouse gas emissions of products and services. At this level, firms take consumption and production decisions constrained by budget as well as by information and technology availability $(20,51)$. Changes at this level occur continuously. Very rapid changes, at a rate of $50 \%$ or more, can occur within a few months. This is shown by public opinion polls on, for example, political preferences following information flows, particularly in online social media (141). Rapid changes in stock markets can occur within hours (142). Nevertheless, such trends rarely lead to bigger changes in human societies without simultaneous institutional 


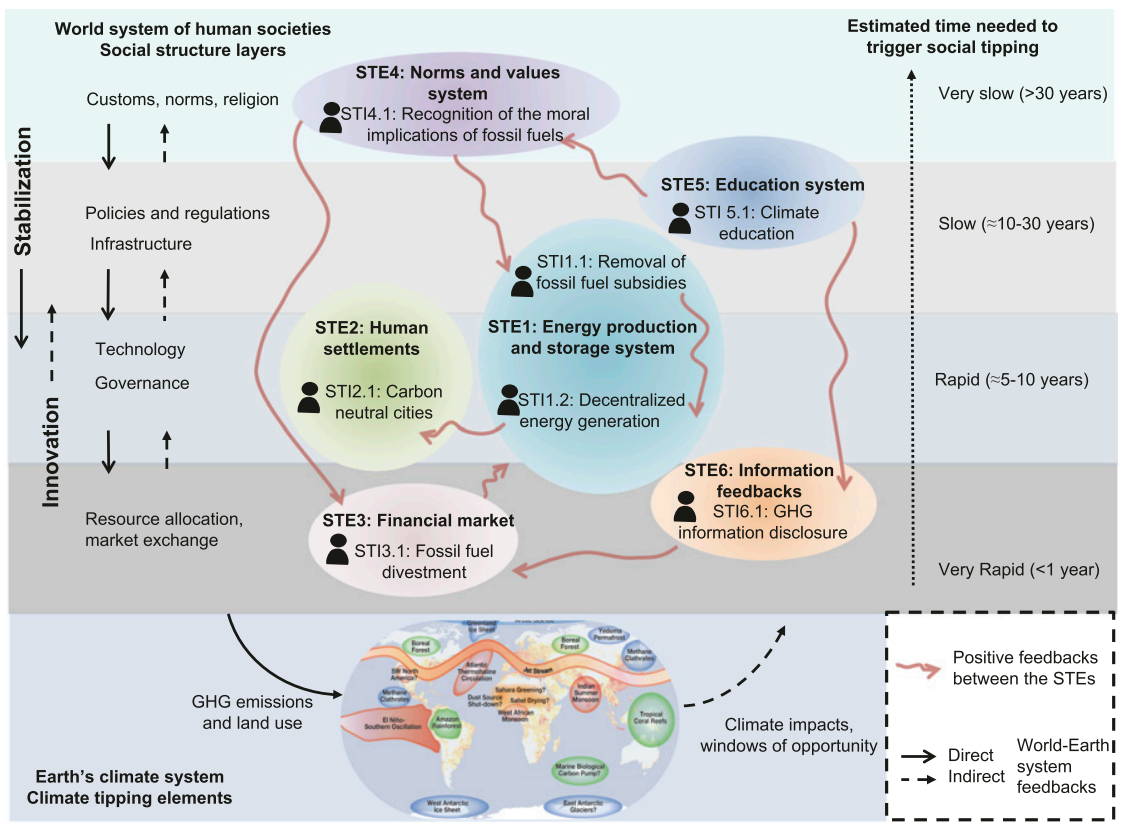

Fig. 3. Social tipping elements (STEs) and associated social tipping interventions (STIs) with the potential to drive rapid decarbonization in the World-Earth system. The processes they represent unfold across levels of social structure on widely different timescales, ranging from the fast dynamics of market exchanges and resource allocation on subannual timescales to the slow decadal- to centennial-scale changes on the level of customs, values, and social norms (51).

changes. The institutional changes, requiring more time, such as transforming the public subsidies and taxation systems, are needed to stabilize the new emerging system. Otherwise the system might become increasingly unstable, bouncing back and forth between the old and new social order, delaying the transformation. A welldocumented example of such a phenomenon is the rebound effect $(143,144)$. Even the frequently quoted "successful" example of feed-in tariffs and German energy transition "Energiewende" to renewables, which used the rapid change in public opinion in the aftermath of the nuclear catastrophe in Fukushima in Japan in 2011, have recently faded away due to the lack of sufficiently sustained societal and policy support (145).

Many of the nominated candidates for STEs extend beyond achieving greenhouse gas reduction and can be potentially interlinked with achieving other global policy goals, such as the Sustainable Development Goals. Many of the interventions discussed above include a range of well-being and public health cobenefits (68). Solving the climate crisis could be a chance to redesign the global socioeconomic institutions toward achieving a more just and equitable future (146). Several authors point out that environmental catastrophes, including increased severity and frequency of climatic extremes, might act as "windows of opportunity" that give rise to uncertainty and confusion, which might in turn motivate actors to engage in reflective processes and take sharp breaks from the existing procedures and policies (147) (Fig. 3 ). However, although the opportunity for a revolutionary change might emerge due to external or environmental factors (148), it is important to actively work with the social complexities (Fig. 2) and the relevant key social actors (Tables 2 and 3), to increase public acceptance and support for the transformative changes to come. To ensure that climate-related social learning will take place, it is necessary to understand how changes of perceptions and awareness, motives, and interests of various actors take place and how institutional innovations occur (149).

We call on both social and natural sciences to engage more intensively in collaborative interdisciplinary research to understand rapid social transformations, STEs, and their interactions with tipping elements in the Earth system. Planetary socialecological models and machine-learning techniques can help to explore the control parameters and critical thresholds in the trajectory of this World-Earth coevolutionary dynamics (43). We also encourage studies on the archetypes of social transformations (150) in different world regions as well as using insights and methods from the natural sciences to study the complexity of social systems. Both empirical studies and modeling exercises could also help to assess the distributional impacts of STIs and factors influencing their effectiveness. Our study presents a comprehensive empirical analysis of social tipping dynamics for global decarbonization. However, since our results were derived from an elicitation process involving small and nonrepresentative samples of experts, more research is needed to verify our findings and to provide more robust empirical evidence and data. Experts from the research sector and the Global North were overrepresented in our sample. Therefore special attention should be given to the expertise of low-carbon and sustainability practitioners as well as to providing more empirical material from the Global South. Finally, the urgency and complex character of climate change require transdisciplinarity and engagement with social movements, knowledge brokers, and change leaders (151). More research is needed on understanding the required social processes and the drivers and incentives for short-term engagement of diverse coalitions of action around concrete solutions and strategies at various governance levels (152).

\section{Materials and Methods}

The primary data collection tool was an online expert survey that was sent to over 1,000 international experts through a private message or addressed through mailing lists of organizations in the field of climate change and sustainability. A full list of all survey questions as well details on the research organization are provided in SI Appendix. The survey ran for $2.5 \mathrm{mo}$, and it was completed by 133 experts. In total, they suggested 207 candidates for STEs and interventions instrumental for decarbonization by 2050 . A selected group of 17 experts were invited for a workshop that focused on choosing the top candidates for STEs. Finally, the coauthors carried out a literature review on the top candidates selected at the workshop, following the literature review guidelines.

Data Availability Statement. All data discussed in the paper will be made available to readers upon request. 
ACKNOWLEDGMENTS. We acknowledge financial support by the Earth League's EarthDoc program, the Stordalen Foundation (http://pb.net/ Network), the Leibniz Association (DominoES), and the European Research Council (Earth Resilience in the Anthropocene). We thank James Greyson,

1. IPCC, Global Warming of $1.5^{\circ} \mathrm{C}$ : An IPCC Special Report on the Impacts of Global Warming of $1.5^{\circ} \mathrm{C}$ above Pre-Industrial Levels and Related Global Greenhouse Gas Emission Pathways, in the Context of Strengthening the Global Response to the Threat of Climate Change, Sustainable Development, and Efforts to Eradicate Poverty, V. MassonDelmotte et al., Eds. (World Meteorological Organization, Geneva, Switzerland).

2. W. Steffen et al., Trajectories of the Earth system in the Anthropocene. Proc. Natl. Acad. Sci. U.S.A. 115, 8252-8259 (2018).

3. W. V. Reid et al., Environment and development. Earth system science for global sustainability: Grand challenges. Science 330, 916-917 (2010).

4. W. Steffen et al., Sustainability. Planetary boundaries: Guiding human development on a changing planet. Science 347, 1259855 (2015).

5. United Nations. Paris Agreement (2015). https://unfccc.int/process-and-meetings/theparis-agreement/the-paris-agreement. Accessed 20 February 2017.

6. J. Rockström et al., A roadmap for rapid decarbonization. Science 355, 1269-1271 (2017).

7. F. W. Geels, Regime resistance against low-carbon transitions: Introducing politics and power into the multi-level perspective. Theory Cult. Soc. 31, 21-40 (2014).

8. C. Kuzemko, M. Lockwood, C. Mitchell, R. Hoggett, Governing for sustainable energy system change: Politics, contexts and contingency. Energy Res. Soc. Sci. 12, 96-105 (2016).

9. B. P. Heard, B. W. Brook, T. M. L. Wigley, C. J. A. Bradshaw, Burden of proof: A comprehensive review of the feasibility of $100 \%$ renewable-electricity systems. Renew. Sustain. Energy Rev. 76, 1122-1133 (2017)

10. H.-W. Sinn, Buffering volatility: A study on the limits of Germany's energy revolution Eur. Econ. Rev. 99, 130-150 (2017)

11. World Bank and Ecofys, Carbon Pricing Watch 2017 (World Bank Group, 2017).

12. S. E. Shmelev, S. U. Speck, Green fiscal reform in Sweden: Econometric assessment of the carbon and energy taxation scheme. Renew. Sustain. Energy Rev. 90, 969-981 (2018).

13. E. Tvinnereim, M. Mehling, Carbon pricing and deep decarbonisation. Energy Policy 121, 185-189 (2018).

14. M. M. Holland, C. M. Bitz, B. Tremblay, Future abrupt reductions in the summer Arctic sea ice. Geophys. Res. Lett. 33, L23503 (2006)

15. T. M. Lenton et al., Tipping elements in the Earth's climate system. Proc. Natl. Acad. Sci. U.S.A. 105, 1786-1793 (2008).

16. V. Dakos, S. R. Carpenter, E. H. van Nes, M. Scheffer, Resilience indicators: Prospects and limitations for early warnings of regime shifts. Phil. Trans. R. Soc. B. 370 20130263 (2015)

17. M. Grodzin, Metropolitan segregation. Sci. Am. 197, 33-41 (1957).

18. T. C. Schelling, Dynamic models of segregation. J. Math. Sociol. 1, 143-186 (1971).

19. C. Doyle, S. Sreenivasan, B. K. Szymanski, G. Korniss, Social consensus and tipping points with opinion inertia. Phys. Stat. Mech. Its Appl. 443, 316-323 (2016).

20. J. D. Farmer et al., Sensitive intervention points in the post-carbon transition. Science 364, 132-134 (2019)

21. B. Walker et al., A handful of heuristics and some propositions for understanding resilience in social-ecological systems. Ecol. Soc. 11, 13 (2006).

22. C. Folke, T. Hahn, P. Olsson, J. Norberg, Adaptive governance of social-ecologica systems. Annu. Rev. Environ. Resour. 30, 441-473 (2005).

23. M. Milkoreit et al., Defining tipping points for social-ecological systems scholarshipan interdisciplinary literature review. Environ. Res. Lett. 13, 033005 (2018).

24. M. U. J. Edwards, Printing, Propaganda and Martin Luther (Fortress Press, 2005).

25. J. E. Trancik et al., Technology improvement and emissions reductions as mutually reinforcing efforts. http://energy.mit.edu/publication/technology-improvement-andemissions-reductions-as-mutually-reinforcing-efforts/. Accessed 20 August 2019.

26. G. Kavlak, J. McNerney, J. E. Trancik, Evaluating the causes of cost reduction in photovoltaic modules. Energy Policy 123, 700-710 (2018).

27. H. J. Schellnhuber, Tipping elements in the Earth system. Proc. Natl. Acad. Sci. U.S.A 106, 20561-20563 (2009)

28. R. E. Kopp, R. Shwom, G. Wagner, J. Yuan, Tipping elements and climate-economic shocks. Earths Futur., 10.1002/2016EF000362 (2016).

29. E. Kriegler et al., A new scenario framework for climate change research: The con cept of shared climate policy assumptions. Clim. Change 122, 401-414 (2014).

30. A. Grubler et al., A low energy demand scenario for meeting the $1.5^{\circ} \mathrm{C}$ target and Sustainable Development Goals without negative emission technologies. Nat. Energy 3, 515-527 (2018)

31. R. C. Hilborn, Sea gulls, butterflies, and grasshoppers: A brief history of the butterfly effect in nonlinear dynamics. Am. J. Phys. 72, 425-427 (2004).

32. E. N. Lorenz, Deterministic nonperiodic flow. J. Atmos. Sci. 20, 130-141 (1963).

33. D. B. Bonar, Molluscan metamorphosis: A study in tissue transformation. Integr. Comp. Biol. 16, 573-591 (1976).

34. J. D. Tàbara et al., Positive tipping points in a rapidly warming world. Curr. Opin Environ. Sustain. 31, 120-129 (2018).

35. S. Lehmann, Y.-Y. Ahn, "Spreading in social systems: Reflections" in Complex Spreading Phenomena in Social Systems: Influence and Contagion in Real-World Social Networks, S. Lehmann, Y.-Y. Ahn, Eds. (Springer International Publishing, 2018), pp. 351-358

36. D. Centola, J. Becker, D. Brackbill, A. Baronchelli, Experimental evidence for tipping points in social convention. Science 360, 1116-1119 (2018).
Claudia Köhler, Sangjun Park, Anja Klein, Andrzej Ancygier, Frank Wechsung Doyne Farmer, Tim Lenton, Jobst Heitzig, Ricarda Winkelmann, Alison Schlums, Maria Martin, Konrad Hagedorn, the WINS Group, and the research participants.

37. C.-F. Schleussner et al., Differential climate impacts for policy-relevant limits to global warming: The case of $1.5{ }^{\circ} \mathrm{C}$ and $2{ }^{\circ} \mathrm{C}$. Earth Syst. Dyn. 7, 327-351 (2016).

38. K. Nyborg et al., Social norms as solutions. Science 354, 42-43 (2016)

39. C. Loftin, Assaultive violence as a contagious social process. Bull. N. Y. Acad. Med. 62, 550-555 (1986)

40. P. Hedström, Contagious collectivities: On the spatial diffusion of Swedish trade unions, 1890-1940. Am. J. Sociol. 99, 1157-1179 (1994).

41. N. A. Christakis, J. H. Fowler, The spread of obesity in a large social network over 32 years. N. Engl. J. Med. 357, 370-379 (2007)

42. N. A. Christakis, J. H. Fowler, The collective dynamics of smoking in a large social network. N. Engl. J. Med. 358, 2249-2258 (2008)

43. J. F. Donges et al., Earth system modelling with complex dynamic human societies: The copan:CORE World-Earth modeling framework. https://doi.org/10.5194/esd-2017126 (15 January 2018).

44. G. Spaargaren, The Ecological Modernization of Production and Consumption. Essays in Environmental Sociology (University of Wageningen, 1997).

45. I. M. Otto et al., Human agency in the anthropocene. Ecol. Econ. 167, 106463 (2020).

46. J. D. Tàbara, C. Pahl-Wostl, Sustainability learning in natural resource use and management. Ecol. Soc. 12, 3 (2007).

47. G. Schreyögg, J. Sydow, Organizational path dependence: A process view. Organ. Stud. 32, 321-335 (2011).

48. E. Dimant, Contagion of pro- and anti-social behavior among peers and the role of social proximity. J. Econ. Psychol. 73, 66-88 (2019).

49. P. Sztompka, Cultural trauma: The other face of social change. Eur. J. Soc. Theory 3 449-466 (2000)

50. United Nations, UN Sustainable Development Goals (2015). https://sustainabledevelopment. un.org/?menu=1300. Accessed 20 May 2017.

51. O. E. Williamson, The new institutional economics: Taking stock, looking ahead. J. Econ. Lit. 38, 595-613 (2000)

52. C. Rammel, S. Stagl, H. Wilfing, Managing complex adaptive systems-a co-evolutionary perspective on natural resource management. Ecol. Econ. 63, 9-21 (2007).

53. R. Koch, The $80 / 20$ Principle: The Secret to Achieving More with Less (Crown Publishing Group, 2011).

54. M. Gladwell, The Tipping Point: How Little Things Can Make a Big Difference (Back Bay Books, 2000).

55. IPCC, Climate Change 2014: Mitigation of Climate Change (Cambridge University Press, 2015)

56. International Renewable Energy Agency. REthinking Energy 2017: Accelerating the global energy transformation (International Renewable Energy Agency, Abu Dhabi, United Arab Emirates, 2017).

57. Breakthrough Energy, Breakthrough Energy Announces Expanded Coalition and Fund Focus Areas, 12 December 2017. https://www.b-t.energy/media-resources/mediarelease-dec-2017/. Accessed 20 February 2018

58. A. D. Foster, M. R. Rosenzweig, Microeconomics of technology adoption. Annu. Rev. Econ. 2, 395-424 (2010).

59. A. McCrone, U. Moslener, F. d'Estais, C. Grüning, Global trends in renewable energy investments. https://euagenda.eu/upload/publications/untitled-87074-ea.pdf. Accessed 20 April 2018

60. G. F. Nemet, Beyond the learning curve: Factors influencing cost reductions in photovoltaics. Energy Policy 34, 3218-3232 (2006).

61. G. J. Dalton, D. A. Lockington, T. E. Baldock, Feasibility analysis of renewable energy supply options for a grid-connected large hotel. Renew. Energy 34, 955-964 (2009).

62. M. Ram et al., Global Energy System Based on 100\% Renewable Energy-Power, Heat, Transport and Desalination Sectors (Lappeenranta University of Technology and Energy Watch Group, 2019).

63. D. L. B. Schwappach, Resource allocation, social values and the QALY: A review of the debate and empirical evidence. Health Expect. 5, 210-222 (2002)

64. P. Griffin, The Carbon Majors Database CDP: Carbon Majors Report 2017. https:// b8f65cb373b1b7b15feb-c70d8ead6ced550b4d987d7c03fcdd1d.ssl.cf3.rackcdn.com/cms/ reports/documents/000/002/327/original/Carbon-Majors-Report-2017.pdf. Accessed 20 February 2018.

65. International Energy Agency, World Energy Outlook 2010. https://webstore.iea.org/ world-energy-outlook-2010. Accessed 18 April 2017

66. H. van Asselt, K. Kulovesi, Seizing the opportunity: Tackling fossil fuel subsidies under the UNFCCC. Int. Environ. Agreement Polit. Law Econ. 17, 357-370 (2017)

67. M. Jakob, C. Chen, S. Fuss, A. Marxen, O. Edenhofer, Development incentives for fossil fuel subsidy reform. Nat. Clim. Chang. 5, 709-712 (2015).

68. D. Coady, I. Parry, L. Sears, B. Shang, How large are global energy subsidies? https:// www.imf.org/en/Publications/WP/lssues/2016/12/31/How-Large-Are-Global-Energy-Subsidies42940. Accessed 20 July 2019.

69. R. McKenna, The double-edged sword of decentralized energy autonomy. Energy Policy 113, 747-750 (2018)

70. M. L. Di Silvestre, S. Favuzza, E. Riva Sanseverino, G. Zizzo, How decarbonization, digitalization and decentralization are changing key power infrastructures. Renew. Sustain. Energy Rev. 93, 483-498 (2018).

71. P. Denholm, M. Hand, Grid flexibility and storage required to achieve very high penetration of variable renewable electricity. Energy Policy 39, 1817-1830 (2011). 
72. J. A. P. Lopes, N. Hatziargyriou, J. Mutale, P. Djapic, N. Jenkins, Integrating distributed generation into electric power systems: A review of drivers, challenges and opportunities. Electr. Power Syst. Res. 77, 1189-1203 (2007).

73. M. Wolsink, The research agenda on social acceptance of distributed generation in smart grids: Renewable as common pool resources. Renew. Sustain. Energy Rev. 16, 822-835 (2012)

74. D. MacKay, Sustainable Energy — Without the Hot Air (UIT Cambridge, 2008)

75. D. Helm, The Carbon Crunch: Revised and Updated (Yale University Press, 2015).

76. R. J. Hewitt et al., Social innovation in community energy in Europe: A review of the evidence. Front. Energy Res. 7, 31 (2019).

77. L. Roy, REWDT trials new Heat Smart project on household heating devices in Orkney (2016). https://www.power-technology.com/uncategorised/newsrewdt-trials-heatsmart-project-household-heating-devices-orkney-4957725/. Accessed 20 July 2019

78. N. Magnani, G. Osti, Does civil society matter? Challenges and strategies of grassroots initiatives in Italy's energy transition. Energy Res. Soc. Sci. 13, 148-157 (2016).

79. T. P. Wright, Factors affecting the cost of airplanes. J. Aeronaut. Sci. 3, 122-128 (1936)

80. P. M. McGuirk, H. Bulkeley, R. Dowling, Configuring urban carbon governance: Insights from Sydney, Australia. Ann. Am. Assoc. Geogr. 106, 145-166 (2016).

81. A. Aylett, Networked urban climate governance. Environ. Plann. C Gov. Policy 31 858-875 (2013)

82. S. J. Davis et al., Net-zero emissions energy systems. Science 360, eaas9793 (2018).

83. P. Hernandez, P. Kenny, From net energy to zero energy buildings: Defining life cycle zero energy buildings (LC-ZEB). Energy Build. 42, 815-821 (2010).

84. J. Laukkonen et al., Combining climate change adaptation and mitigation measures at the local level. Habitat Int. 33, 287-292 (2009).

85. D. M. Roodman, N. Lenssen, A Building Revolution: How Ecology and Health Concerns are Transforming Construction (Worldwatch Institute, 1995).

86. M. E. Porter, Location, competition, and economic development: Local clusters in a global economy. Econ. Dev. Q. 14, 15-34 (2000).

87. J. W. G. Van De Kuilen, A. Cecotti, Z. Xia, M. He, Very tall wooden buildings with cross laminated timber. Procedia Eng. 14, 1621-1628 (2011).

88. N. Bardsley, J. Mehta, C. Starmer, R. Sugden, Explaining focal points: Cognitive hierarchy theory versus team reasoning. Econ. J. (Lond.) 120, 40-79 (2010).

89. G. Feola, R. Nunes, Success and failure of grassroots innovations for addressing climate change: The case of the Transition Movement. Glob. Environ. Change 24, 232-250 (2014).

90. Energy Cities, Vision and mission. https://energy-cities.eu/vision-mission/. Accessed 30 December 2019.

91. Energy Cities, Fossil fuel free Växjö. http://enercitee.eu/files/dokumente/Policy maker exchange/Fossil_Fuel_Free_Vaxjo_-_the_story_2010.pdf. Accessed 20 May 2018.

92. M. Campello, J. R. Graham, C. R. Harvey, The real effects of financial constraints: Evidence from a financial crisis. J. Financ. Econ. 97, 470-487 (2010).

93. B. Ott, "The carbon asset bubble-mythos or menace? An attempted refutation" Bachelor thesis, Hochschule für Wirtschaft und Recht Berlin, Berlin, Germany (2016).

94. J. Ritchie, H. Dowlatabadi, Divest from the carbon bubble? Reviewing the implication and limitations of fossil fuel divestment for institutional investors. Rev. Econ. Finance 5, 59-80 (2015)

95. J. Rubin, The Carbon Bubble (Random House, 2015).

96. B. Ewers, J. F. Donges, J. Heitzig, S. Peterson, Divestment may burst the carbon bubble if investors' beliefs tip to anticipating strong future climate policy. arXiv: 1902.07481 (20 February 2019).

97. G. A. Lenferna, "Divestment as climate justice: Weighing the power of the fossil fue divestment movement" in Climate Justice and the Economy: Social Mobilization, Knowledge and the Political, S. G. Jacobsen, Ed. (Routledge Earth Scan, 2018), pp 84-109.

98. D. Carrington, Fossil fuel divestment funds double to $\$ 5$ th in a year, The Guardian 16 December 2016. https://www.theguardian.com/environment/2016/dec/12/fossil-fueldivestment-funds-double-5tn-in-a-year. Accessed 20 September 2018.

99. N. Healy, J. Barry, Politicizing energy justice and energy system transitions: Fossil fuel divestment and a "just transition." Energy Policy 108, 451-459 (2017).

100. O. Ralph, Insurers go cold on coal industry. Financial Times, 7 January 2018. https:// www.ft.com/content/7ec63f34-f20c-11e7-ac08-07c3086a2625. Accessed 20 May 2018.

101. A. Vaughan, World's biggest sovereign wealth fund proposes ditching oil and gas holdings. The Guardian, 16 November 2017. https://www.theguardian.com/business/ 2017/nov/16/oil-and-gas-shares-dip-as-norways-central-bank-advises-oslo-to-divest. Accessed 22 May 2018.

102. I. M. Otto et al., Social vulnerability to climate change: A review of concepts and evidence. Reg. Environ. Change 17, 1651-1662 (2017).

103. H. J. Schellnhuber et al., "The challenge of a 4 degrees celsius world by 2100 " in Hexagon Series on Human Environmental Security and Peace, H. G. Brauch, Ed. (Springer, 2016), pp. 267-283.

104. M. Kampa, E. Castanas, Human health effects of air pollution. Environ. Pollut. 151, 362-367 (2008)

105. P. Simpson, C. Hill, "Leadership, spirituality and complexity: Wilberforce and the abolition of the slave trade" in Leadership Perspectives, K. T. James, J. Collins, Eds. (Palgrave Macmillan, 2008), pp. 29-42.

106. R. Gifford, The dragons of inaction: Psychological barriers that limit climate change mitigation and adaptation. Am. Psychol. 66, 290-302 (2011).

107. E. M. Rogers, Diffusion of Innovations (Simon and Schuster, ed. 4, 2010).

108. P. Francis, Encyclical Letter Laudato Si' of the Holy Father Francis on Care for Our Common Home (Vatikan Press, 2015).

109. C. Freund, S. Oliver, The Origins of the superrich: The billionaire characteristics database (2016). https://papers.ssrn.com/abstract=2731353. Accessed 6 February 2019.

110. R. A. Posner, Social norms and the law: An economic approach. Am. Econ. Rev. 87, 365-369 (1997)
111. F. Green, Anti-fossil fuel norms. Clim. Change 150, 103-116 (2018).

112. G. J. M. Velders, S. O. Andersen, J. S. Daniel, D. W. Fahey, M. McFarland, The importance of the Montreal Protocol in protecting climate. Proc. Natl. Acad. Sci. U.S.A 104, 4814-4819 (2007)

113. D. Evensen, The rhetorical limitations of the \#FridaysForFuture movement. Nat. Clim. Chang. 9, 428-433 (2019).

114. J. Lin, Social Transformation and Private Education in China (Praeger Publishers, 1999).

115. W. Lutz, R. Muttarak, E. Striessnig, Environment and development. Universal education is key to enhanced climate adaptation. Science 346, 1061-1062 (2014).

116. T. M. Lee, E. M. Markowitz, P. D. Howe, C.-Y. Ko, A. A. Leiserowitz, Predictors of public climate change awareness and risk perception around the world. Nat. Clim. Chang. 5, 1014-1020 (2015)

117. E. Plutzer et al., Climate confusion among U.S. teachers. Science 351, 664-665 (2016)

118. I. Lorenzoni, S. Nicholson-Cole, L. Whitmarsh, Barriers perceived to engaging with climate change among the UK public and their policy implications. Glob. Environ. Change 17, 445-459 (2007)

119. Z. W. Kundzewicz et al., Uncertainty in climate change impacts on water resources. Environ. Sci. Policy 79, 1-8 (2018)

120. A. Kempf, The Cuban literacy campaign at 50: Formal and tacit learning in revolutionary education. Crit. Educ., 10.14288/ce.v5i4.183269 (2014).

121. S. Suranovic, Fossil fuel addiction and the implications for climate change policy. Glob. Environ. Change 23, 598-608 (2013).

122. K. E. Warner, The effects of the anti-smoking campaign on cigarette consumption Am. J. Public Health 67, 645-650 (1977).

123. T. Dietz, G. T. Gardner, J. Gilligan, P. C. Stern, M. P. Vandenbergh, Household actions can provide a behavioral wedge to rapidly reduce US carbon emissions. Proc. Natl. Acad. Sci. U.S.A. 106, 18452-18456 (2009).

124. Life, R.A.C.E.S. (Raising Awareness on Climate Change and Energy Saving): Final Report. http://ec.europa.eu/environment/life/project/Projects/index.cfm?fuseaction=home. showFile\&rep=file\&fil=LIFE07_INF_IT_000487_FTR.pdf. Accessed 20 April 2018.

125. M. S. McCaffrey, Climate Smart \& Energy Wise: Advancing Science Literacy, Knowledge and Know-How (Corwin, 2014).

126. D. W. O'Neill, A. L. Fanning, W. F. Lamb, J. K. Steinberger, A good life for all within planetary boundaries. Nat. Sustain. 1, 88-95 (2018)

127. M. Freedman, J. D. Park, A. J. Stagliano, "Mandated climate change disclosures: A study of large US firms that emit carbon dioxide" in Sustainability and Governance C. R. Lehman, Ed. (Emerald Publishing, 2015), pp. 99-121.

128. D. Brounen, N. Kok, On the economics of energy labels in the housing market J. Environ. Econ. Manage. 62, 166-179 (2011).

129. J. Andrew, C. Cortese, Accounting for climate change and the self-regulation of carbon disclosures. Account. Forum 35, 130-138 (2011).

130. H. Forst, Das ist die Mitte der Gesellschaft. Zeit, 6 October 2018. https://www.zeit.de/ gesellschaft/2018-10/hambacher-forst-demonstration-rodung-rwe-armin-laschet. Accessed 24 October 2018.

131. J. Ayling, N. Gunningham, Non-state governance and climate policy: The fossil fuel divestment movement. Clim. Policy 17, 131-149 (2017).

132. I. Otto-Banaszak, P. Matczak, J. Wesseler, F. Wechsung, Different perceptions of adaptation to climate change: A mental model approach applied to the evidence from expert interviews. Reg. Environ. Change 11, 217-228 (2011).

133. K. Meyer, P. Newman, The planetary accounting framework: A novel, quota-based approach to understanding the impacts of any scale of human activity in the context of the planetary boundaries. Sustain. Earth 1, 4 (2018).

134. A. Sahota, "The global market for organic food and drink" in The World of Organic Agriculture: Statistics and Emerging Trends 2008, H. Willer, M. Yussefi-Menzler, N. Sorensen, Eds. (Routledge, 2008), pp. 53-58.

135. B. C. O'Neill et al., A new scenario framework for climate change research: The concept of shared socioeconomic pathways. Clim. Change 122, 387-400 (2014)

136. J. Mezirow, Transformative learning: Theory to practice. New Dir. Adult Contin. Educ. 1997, 5-12 (1997).

137. F. Gathmann, C. Hecking, CDU und CSU im Ökomodus: Plötzlich grün (Spiegel Online 2019).

138. O. E. Williamson, Transaction costs economics: How it works; where it is headed. Econ. 146, 23-58 (1998).

139. H. Coffey, What is "flygskam"? Everything you need to know about the environmental movement that's sweeping Europe. The Independent, 5 June 2019. https:// www.independent.co.uk/travel/news-and-advice/flygskam-anti-flying-flight-shaming sweden-greta-thornberg-environment-air-travel-train-brag-a8945196.html. Accessed 7 June 2019.

140. E. Graham-Harrison, A quiet revolution sweeps Europe as Greens become a political force. The Observer, 2 June 2019. https://www.theguardian.com/politics/2019/jun/02/ european-parliament-election-green-parties-success. Accessed 7 June 2019.

141. B. O'Connor, R. Balasubramanyan, B. R. Routledge, N. A. Smith, "From tweets to polls: Linking text sentiment to public opinion time series" in Proceedings of the International AAAl Conference on Weblogs and Social Media (Association for the Advancement of Artificial Intelligence, 2010), pp. 122-129.

142. D. M. Kotz, The financial and economic crisis of 2008: A systemic crisis of neoliberal capitalism. Rev. Radic. Polit. Econ. 41, 305-317 (2009).

143. W. S. Jevons, The Coal Question: An Inquiry Concerning the Progress of the Nation, and the Probable Exhaustion of Our Coal-Mines (Augustus M. Kelley, 1965).

144. R. Cremades et al., Co-benefits and trade-offs in the water-energy nexus of irrigation modernization in China. Environ. Res. Lett. 11, 054007 (2016).

145. C. Kemfert, Germany must go back to its low-carbon future. Nature 549, 26-27 (2017). 
146. WBGU, Welt im Wandel. Gesellschaftsvertrag für eine Große Tranformation (Wissenschaftlicher Beitrat der Budesregierung Globale Umweltveränderungen, 2011).

147. T. R. Burns, "Two conceptions of human agency: Rational choice theory and the social theory of action" in Agency and Structure. Reorienting Social Theory, Piotr Sztompka, Ed. (Gordon and Breach Science Publishers, 1994), pp. 197-250.

148. W. J. Abernathy, K. B. Clark, Innovation: Mapping the winds of creative destruction Res. Policy 14, 3-22 (1985).

149. J. D. Tàbara et al., The climate learning ladder. A pragmatic procedure to support climate adaptation. Environ. Policy Gov. 20, 1-11 (2010).

150. K. Eisenack et al., Design and quality criteria for archetype analysis. Ecol. Soc. 24, 6 (2019).

151. F. Westley et al., Tipping toward sustainability: Emerging pathways of transformation Ambio 40, 762-780 (2011).

152. S. Aakre, S. Kallbekken, R. V. Dingenen, D. G. Victor, Incentives for small clubs of Arctic countries to limit black carbon and methane emissions. Nat. Clim. Chang. 8, 85 (2018).

153. D. P. van Vuuren et al., The representative concentration pathways: An overview. Clim. Change 109, 5-31 (2011).

154. J. Rogelj, M. Meinshausen, R. Knutti, Global warming under old and new scenarios using IPCC climate sensitivity range estimates. Nat. Clim. Chang. 2, 248-253 (2012).

155. M. Scheffer et al., Early-warning signals for critical transitions. Nature 461, 53-59 (2009).

156. A. Ganopolski, S. Rahmstorf, Abrupt glacial climate changes due to stochastic resonance. Phys. Rev. Lett. 88, 038501 (2002)

157. J. H. Jo, J. S. Golden, S. W. Shin, Incorporating built environment factors into climate change mitigation strategies for Seoul, South Korea: A sustainable urban systems framework. Habitat Int. 33, 267-275 (2009).

158. J. Lipp, Lessons for effective renewable electricity policy from Denmark, Germany and the United Kingdom. Energy Policy 35, 5481-5495 (2007).

159. M. A. Boutabba, S. Lardic, EU emissions trading scheme, competitiveness and carbon leakage: New evidence from cement and steel industries. Ann. Oper. Res. 255, 47-61 (2017).

160. D. W. Keith, G. Wagner, C. L. Zabel, Solar geoengineering reduces atmospheric carbon burden. Nat. Clim. Chang. 7, 617-619 (2017)

161. S. Jacobsson, V. Lauber, The politics and policy of energy system transformationExplaining the German diffusion of renewable energy technology. Energy Policy 34, 256-276 (2006).

162. O. Wagner, K. Berlo, "The wave of remunicipalisation of energy networks and supply in Germany : The establishment of 72 new municipal power utilities" in ECEEE 2015 Summer Study on Energy Efficiency: First Fuel Now (European Council for an Energy Efficient Economy, Stockholm, 2015).
163. R. Bolton, T. J. Foxon, Infrastructure transformation as a socio-technical processImplications for the governance of energy distribution networks in the UK. Technol. Forecast. Soci. Change 90, 538-550 (2015).

164. B. Zeng et al., Integrated planning for transition to low-carbon distribution system with renewable energy generation and demand response. IEEE Trans. Power Syst. 29, 1153-1165 (2014).

165. A. Yadoo, H. Cruickshank, The role for low carbon electrification technologies in poverty reduction and climate change strategies: A focus on renewable energy minigrids with case studies in Nepal, Peru and Kenya. Energy Policy 42 (suppl. C), 591-602 (2012).

166. D. Hoornweg, L. Sugar, and C. L. T. Gómez, Cities and greenhouse gas emissions: Moving forward. Environ. Urban. 23, 207-227 (2011).

167. J. Ritchie, H. Dowlatabadi, Life cycle impacts of divestment: Applying an economic input-output LCA model to measure financed emissions. https://open.library.ubc.ca/ CIRcle/collections/graduateresearch/42591/items/1.0075807. Accessed 28 September 2018.

168. A. Hares, J. Dickinson, K. Wilkes, Climate change and the air travel decisions of UK tourists." J. Transp. Geogr. 18, 466-473 (2010).

169. The Lancet Planetary Health, Power to the children. Lancet Planet. Health 3, PE102 (2019).

170. P. C. Stern, T. Dietz, T. Abel, G. A. Guagnano, L. Kalof, A value-belief-norm theory of support for social movements: The case of environmentalism. Hum. Ecol. Rev. 6, 81-97 (1999).

171. A. M. Padilla, W. Perez, Acculturation, social identity, and social cognition: A new perspective. Hisp. J. Behav. Sci. 25, 35-55 (2003).

172. E. A. Nadelmann, Global prohibition regimes: The evolution of norms in international society. Int. Organ. 44, 479-526 (1990).

173. M. Story, M. S. Nanney, M. B. Schwartz, Schools and obesity prevention: Creating school environments and policies to promote healthy eating and physical activity. Milbank Q. 87, 71-100 (2009).

174. S. Cowan, C. Deegan, Corporate disclosure reactions to Australia's first national emission reporting scheme. Accounting \& Finance 51, 409-436 (2011).

175. P. Upham, L. Dendler, M. Bleda, Carbon labelling of grocery products: Public perceptions and potential emissions reductions. J. Clean. Prod. 19, 348-355 (2011).

176. A. Fraser, Are investment carbon footprints good for investors and the climate? Policy Options (2017). http://policyoptions.irpp.org/magazines/november-2017/areinvestment-carbon-footprints-good-for-investors-and-the-climate/. Accessed 20 September 2018.

177. A. Banerjee, B. D. Solomon, Eco-labeling for energy efficiency and sustainability: A meta-evaluation of US programs. Energy Policy 31, 109-123 (2003).

178. I. Siró, E. Kápolna, B. Kápolna, A. Lugasi, Functional food. Product development, marketing and consumer acceptance-A review. Appetite 51, 456-467 (2008). 